\title{
WYBRANE ASPEKTY REWITALIZACJI OSIEDLA STARY FORDON W BYDGOSZCZY - PROJEKTY I OPINIE MIESZKAŃCÓW
}

\author{
SELECTED ASPECTS OF REVITALIZATION \\ OF THE STARY FORDON ESTATE IN BYDGOSZCZ - \\ DESIGNS AND OPINIONS OF RESIDENTS
}

NR DOI: $10.25167 / \mathrm{sm} 2018.032 .04 \quad$ s. $47-68$

\begin{abstract}
ABSTRAKT: Celem pracy jest ocena koncepcji rewitalizacji przestrzennej i społecznej osiedla Stary Fordon w Bydgoszczy w nawiązaniu do historii tego miejsca oraz zmian społecznych, a także ukazanie wszelkich działań, które zostały już w tym kierunku poczynione. Zakres czasowy pracy obejmuje lata 2014-2016. Główne prace polegały na kwerendzie materiałów źródłowych oraz przeprowadzeniu ankiety z mieszkańcami. W efekcie stwierdzono, że Stary Fordon to obszar o dużej wartości i potencjale, który dotyczy zarówno zasobów przestrzeni, jak i lokalnej społeczności. Ogólna ocena obecnie obowiązującej koncepcji rewitalizacji jest pozytywna. Trzeba jednak przyznać, że projekt nie spełnia wszystkich potrzeb mieszkańców. Należałoby rozwinąć przede wszystkim działania miękkie, społeczne
\end{abstract}

SŁOWA KLUCZOWE: rewitalizacja, przestrzeń miejska, Stary Fordon, Wisła, koncepcja, społeczność lokalna.

ABSTRACT: The aim of the work is to evaluate the concept of spatial and social revitalization of the Stary Fordon housing estate in Bydgoszcz in reference to the history of this place and social changes, as well as to show all activities that have already been undertaken in this direction. The time frame of the work covers the years 2014-2016. The main tasks consisted in carrying out a query of source materials and conducting a survey with residents. As a result, it was stated that Stary Fordon is an area of high value and potential, which concerns both the resources of space and the local community. The overall assessment of the current revitalization concept is positive. However, it must be admitted that the project does not meet all the needs of the residents. It appears that it is mainly soft social activities which should be developed.

KEY WORDS: revitalization, urban space, Stary Fordon, the Vistula, concept, local community

\footnotetext{
* Uniwersytet Gdański, Wydział Oceanografii i Geografii, Katedra Hydrologii, e-mail: georc@univ.gda.pl
} 


\section{Wprowadzenie}

Współcześnie w przestrzeni miejskiej coraz więcej jest terenów zdegradowanych, negatywnie wpływających na wizerunek miasta oraz pogłębianie istniejących problemów społecznych (Ferber et al. 2006). W Europie Zachodniej od lat 60. XX w. do dzisiaj jednym z narzędzi służących do naprawy zdegradowanych fragmentów miasta jest rewitalizacja (Kaczmarek 2001). Jak uważa J. Kaczmarek (2010), istotą tego procesu przekształceń przestrzeni miejskiej jest sekwencja planowych działań, które mają na celu ożywienie gospodarcze oraz zmianę struktury przestrzennej i funkcjonalnej zdegradowanych obszarów miasta. O tym, jak ma przebiegać sam proces rewitalizacji, mówi ustawa o rewitalizacji z 2015 r. ${ }^{1}$ Wskazuje ona zasady oraz tryb przygotowania, prowadzenia i oceny rewitalizacji. Tak więc proces rewitalizacji polega na przywracaniu do życia obszarów zdegradowanych. Prowadzone działania rewitalizacyjne mają charakter kompleksowy, a ich celem jest poprawa warunków życia na danym obszarze czy spowodowanie korzystnych zmian w przestrzeni, a także eliminacja patologii społecznych (Kotus 2005; Lorens 2009) i zmniejszenie poczucia alienacji określonych grup społecznych (Szarfenberg 2007). Polegają one przede wszystkim na przeciwdziałaniu negatywnym tendencjom społecznym oraz zwiększaniu poczucia bezpieczeństwa i integracji mieszkańców (Herbst 2008), choć to ostatnie jest trudne ze względu na fakt, że ludzie ci się nie znają (Šafránková 2005). Według E. Szafrańskiej (2010) rewitalizacja miast to jednoczesne zmiany w aspekcie społeczno-demograficznym, przestrzennym i funkcjonalnym. Zmienia się też ich fizjonomia oraz społeczna percepcja, stają się bardziej przyjaznym i akceptowalnym środowiskiem mieszkaniowym. Można zatem stwierdzić, że zmiany te powodują przekształcenia strukturalne miast bądź ich fragmentów (Madurowicz 2002; Parysek 2005).

Tematem pracy jest proces rewitalizacji osiedla Stary Fordon w Bydgoszczy. Obecnie podejmuje się coraz więcej działań mających prowadzić do odbudowy wizerunku Bydgoszczy jako dobrze rozwijającego się, nowoczesnego miasta o dużych walorach estetycznych i kulturalnych. Położenie miasta nad rzekami - Wisłą i Brdą - jest dodatkowo jednym z największych jego atutów, przez co istotną perspektywą na przyszłość staje się przywrócenie nadrzecznej oraz historyczno-kulturalnej tożsamości mieszkańców. Jednym z kluczowych środków niezbędnych do osiągnięcia tego celu jest rozwój rekreacji nadwodnej. Z pewnością przyczyniłoby się to do zwiększenia integracji społecznej, a także powstania specyficznego „klimatu” miasta i co za tym idzie - wzrostu jego konkurencyjności. Coraz więcej uwagi poświęcono w ostatnich latach promowaniu nadrzecznych terenów Brdy, a na boczny tor odsunięte zostały równie cenne pod względem krajobrazu i możliwości rekreacji nabrzeża Wisły w Fordonie. Nie tylko jednak nadrzeczne położenie stanowi istotę tożsamości bydgoszczan. Dla mieszkańców Starego Fordonu ważna jest historia tego osiedla jako miejsca zamieszkiwanego w dużej mierze przez ludność żydowską. Jest to jednak problem trudny, gdyż ubytek naturalny

1 Dz.U. z 2015 r., poz. 1777 z późn. zm. 
i starzenie się społeczeństwa oraz ubóstwo powodujące różnego rodzaju uzależnienia, szczególnie wśród młodzieży, nie sprzyjają „odnowie” danego miejsca (Rysz-Kowalczyk (red.) 2001; Niezabitowska 2015). Również brak spójności i sprawiedliwości społecznej może być tego przyczyną (Wańkowicz 2011).

Celem pracy jest przedstawienie i ocena koncepcji rewitalizacji przestrzennej i społecznej osiedla Stary Fordon w Bydgoszczy w nawiązaniu do historii tego miejsca oraz zgodnie z potrzebami jego mieszkańców, a także ukazanie wszelkich działań, które zostały już w tym kierunku podjęte. Zakres czasowy obejmuje lata 2014-2016. Pod względem przestrzennym praca obejmuje cały obszar osiedla Stary Fordon, a więc rdzennej części dzielnicy Fordon w Bydgoszczy (ryc. 1), położonej nad rzeką Wisłą.
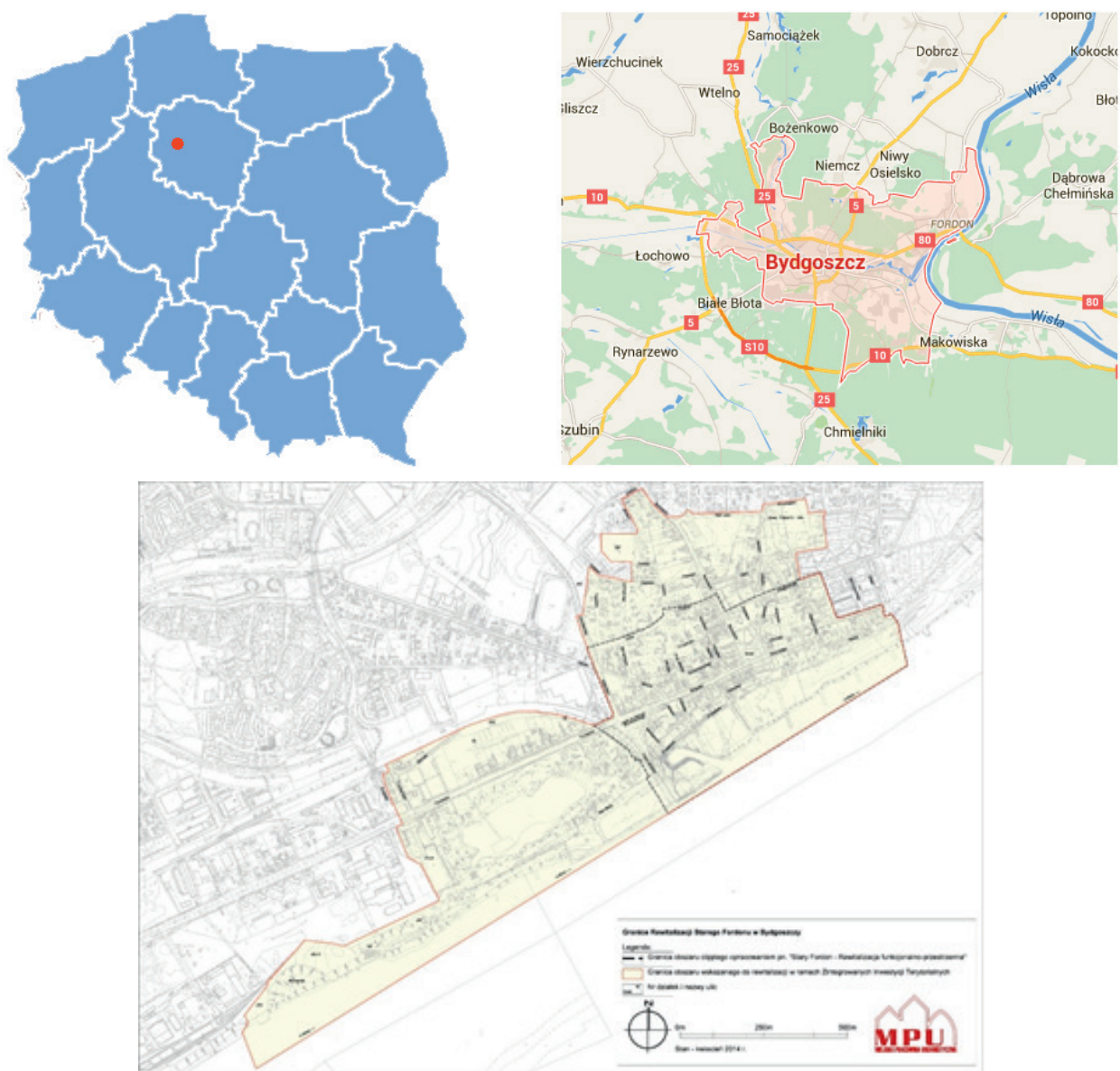

Ryc. 1. Lokalizacja osiedla Stary Fordon na tle Polski oraz miasta Bydgoszcz (wraz z granicami osiedla wyznaczonymi w ramach Zintegrowanych Inwestycji Terytorialnych i obszaru wskazanego do rewitalizacji przez Miejską Pracownię Urbanistyczną w Bydgoszczy)

Źródło: wikimapia.org; mpu.bydgoszcz.pl. 
Zasadniczej analizie zostanie jednak poddana część osiedla obecnie wyznaczona do rewitalizacji przez władze miasta (ograniczona od strony południowej rzeką Wisłą, od zachodu - ul. Flotylli Wiślanej i ul. Ametystową, od północy ul. Saską, ul. Krygera i ul. Pielęgniarską, a od wschodu ul. Kapeluszników i ul. Rybaki do numeru 5), poszerzona o niezagospodarowany teren zieleni przy ul. Saskiej - tuż za granicą obszaru.

Stary Fordon położony jest w mikroregionie Przełom Doliny Wisły. Jest to część mezoregionu Dolina Fordońska, która należy do makroregionu Dolina Dolnej Wisły (Kondracki 2001). Przełom Doliny Wisły zwany jest także Fordońskim Przełomem Wisły (Banaszak 1996).

\section{Metody badań}

Główne prace polegały na kwerendzie materiałów źródłowych. Jedną z najistotniejszych kwestii było zgromadzenie i analiza dokumentów planistycznych, co pozwoliło na określenie możliwości rozwoju obszaru osiedla Stary Fordon pod względem przestrzennym. Większość z danych uzyskano poprzez strony internetowe ${ }^{2}$. W celu przygotowania dokładnej charakterystyki terenu oraz opisu aktualnego stanu jego zabudowy i zagospodarowania przeprowadzone zostały w lipcu 2016 r. badania terenowe. Polegały one głównie na sporządzeniu dokumentacji fotograficznej.

W aspekcie społecznym bardzo przydatna okazała się ankieta przeprowadzona zarówno wśród mieszkańców Starego Fordonu, jak i osób reprezentujących inne osiedla Bydgoszczy. W ankiecie wzięło udział 150 osób, z czego 65\% stanowiły kobiety. Ankieta była prowadzona bezpośrednio w terenie. Ponad połowa respondentów (53\%) to osoby mieszkające w Starym Fordonie. Pozostali to mieszkańcy innych bydgoskich osiedli, którzy chcieli wyrazić swoje zdanie na temat badanego obszaru. Zazwyczaj często bywają oni w Starym Fordonie (69\%), aby odwiedzić rodzinę lub znajomych czy też odpocząć na łonie przyrody. Niektórzy jednak nie jeżdżą tam wcale (6\%) ze względu na dużą odległość do pokonania i brak ciekawych form rozrywki na terenie osiedla.

Pod względem struktury wiekowej najwięcej ankietowanych było w wieku między 36. a 65. rokiem życia. Równie dużą część stanowiły osoby młode (44\%). Najmniej było osób w starszym wieku (tylko 8\%). Większość respondentów posiadała wykształcenie wyższe (56\%) oraz średnie lub zasadnicze zawodowe (42\%). Ponad połowę ankietowanych stanowiły osoby zatrudnione na umowę, a tylko 14,5\% prowadziło własną działalność gospodarczą. Należy dodać, że część respondentów to także osoby bezrobotne, emeryci i renciści.

Ankieta podzielona została na dwie części - wspólną, skierowaną do wszystkich ankietowanych oraz część przeznaczoną tylko dla mieszkańców osiedla Stary Fordon. Pytania miały charakter w dużym stopniu otwarty, przy większości z nich istniała możliwość uzasadnienia wyboru odpowiedzi. W części wspólnej pytania dotyczyły

\footnotetext{
${ }^{2}$ www.staryfordon.pl; www.zdmikp.bydgoszcz.pl; www.fundacja.ukw.edu.pl; www.mpu.bydgoszcz.pl.
} 
m.in. tego, z czym kojarzy się ankietowanym Stary Fordon i jak jest postrzegany w porównaniu do innych bydgoskich osiedli. Ankietowani zostali zapytani o to, jak często bywają na Starym Fordonie, czy czują się tam bezpiecznie i czego według nich najbardziej w tym miejscu brakuje. Ponadto możliwe było zgłaszanie własnych pomysłów dotyczących proponowanych zmian na terenie osiedla. Odpowiedzi zebrane w drugiej części ankiety pozwoliły dodatkowo na określenie, jak ankietowani mieszkańcy Starego Fordonu oceniają poziom wzajemnej integracji społecznej, czy pracują na terenie tegoż osiedla, oraz ilu spośród nich korzysta ze świadczeń pomocy społecznej. Wyniki ankiety i wnioski z nich płynące zostały przedstawione w dalszej części pracy. Poniżej przedstawiono pełen zakres pytań i możliwych odpowiedzi.

1. Czy jest Pan/Pani mieszkańcem Starego Fordonu?

a. tak (wypełnij obie części ankiety)

b. nie (wypełnij tylko CZĘŚĆ WSPÓLNĄ)

CZĘŚĆ WSPÓLNA (dla wszystkich ankietowanych)

2. Z czym kojarzy się Panu/Pani Stary Fordon?

3. Jak często bywa Pan/Pani w Starym Fordonie?

a. jestem mieszkańcem osiedla Stary Fordon

b. bywam tam bardzo często, ponieważ

c. bywam tam czasami, ponieważ

d. nie jeżdżę tam

4. Czy jest coś, czego mieszkańcy pozostałych osiedli Bydgoszczy mogą pozazdrościć mieszkańcom Starego Fordonu?

5. Czego najbardziej brakuje Panu/Pani na osiedlu Stary Fordon?
a. kultury i rozrywki
b. miejsc sportu i rekreacji
c. dobrego stanu technicznego zabudowy i infrastruktury
d. lepszej jakości środowiska przyrodniczego
e. dobrej komunikacji publicznej z centrum miasta
f. bazy gastronomicznej
g. ścieżek rowerowych
h. inne, jakie?

6. Czy czuje się Pan/Pani bezpiecznie na Starym Fordonie w porównaniu do innych osiedli Bydgoszczy?
a. tak, ponieważ
b. nie, ponieważ
c. nie jeżdżę tam

7. Inne uwagi / proponowane zmiany na osiedlu:

\section{CZĘŚĆ DLA MIESZKAŃCÓW OSIEDLA STARY FORDON}

8. Czy pracuje Pan/Pani na terenie osiedla Stary Fordon?

a. tak 

b. nie, ponieważ
c. nie jestem osobą pracującą

9. Czy jest Pan/Pani osobą korzystającą z pomocy społecznej?
a. tak
b. nie

10. Jak ocenia Pan/Pani poziom integracji społecznej mieszkańców osiedla?
a. wysoki, ponieważ
b. średni, ponieważ
c. inni mieszkańcy są mi zupełnie obcy, ponieważ

\section{METRYCZKA}

Płeć: kobieta / mężczyzna

Wiek: poniżej 18 / 19-25 / 26-35 / 36-55 / 56-65 / powyżej 65 lat

Wykształcenie: podstawowe (gimnazjalne) / średnie lub zasadnicze zawodowe / wyższe Aktywność zawodowa: osoba pracująca na własny rachunek (firma) / osoba zatrudniona na umowę / osoba niepracująca / osoba ucząca się / emeryt lub rencista

\section{Stan istniejący obszaru badań pod względem przestrzennym}

Stary Fordon to osiedle Bydgoszczy stanowiące niewielką, pierwotną część Fordonu - wschodniej dzielnicy miasta. Do 1973 r. stanowił samodzielne miasto (Jankowski 2011). Osiedle to wyróżnia się na tle innych jednostek Bydgoszczy historią. Dzieje tego miejsca, jego dziedzictwo historyczne i kulturowe doprowadziły do wytworzenia dużo większego poczucia przynależności i więzi mieszkańców ze Starym Fordonem niż w przypadku osób zamieszkujących inne osiedla Bydgoszczy. Wzmianka na temat nazwy Fordon po raz pierwszy pojawiła się w 1409 r. i związana była z określeniem pobieranego tam cła rzecznego - fordonu. Mianem tym określano podatek pobierany przy wpływaniu na Wisłę z jej lewych dopływów (m.in. Brdy) (Biegański 1997).

Stary Fordon pod względem struktury przestrzenno-funkcjonalnej można podzielić na tereny z dominującą zabudową mieszkaniową, usługową, tereny o funkcjach mieszkalno-usługowych oraz zieleń (głównie nadrzeczną). Poza tym występuje również niewielka ilość terenów o funkcji przemysłowej, cmentarze, tereny komunikacyjne i te zajmowane przez infrastrukturę techniczną. Największą powierzchnię zajmuje mieszkalnictwo jednorodzinne, obejmujące większość osiedla, a zwłaszcza jego część północną i zachodnią. Pozostały obszar zabudowy mieszkaniowej stanowią kamienice wielorodzinne oraz bloki mieszkalne. Skupiska bloków są niewielkie, położone na zachodnich krańcach osiedla i w rejonie ul. Fordońskiej. Funkcje usługowe natomiast zlokalizowane są najczęściej w parterach kamienic wielorodzinnych, a miejscami również w odrębnych budynkach. Tereny usługowe w przeważającej części usytuowane są w okolicach rynku oraz przy głównych ulicach. Generalnie na terenie osiedla dominuje niska przedwojenna zabudowa znajdująca się w złym stanie technicznym. Dotyczy to przede wszystkim lokacyjnej (pierwotnej) części Starego Fordonu i wpływa na specyficzny klimat tego 
miejsca. Nowe budownictwo reprezentowane jest jedynie przez część domów jednorodzinnych o charakterze willowym, zazwyczaj oddalonych od historycznego centrum obszaru. Fragment osiedla objęty szczegółowo niniejszym opracowaniem nie zawiera części nowszej zabudowy obrzeży Starego Fordonu (zabudowy willowej i blokowisk).

Bardzo zły stan techniczny znacznej części zabudowy mieszkalnej i usługowej osiedla dotyczy nie tylko starych kamienic wielorodzinnych, ale również wielu domów jednorodzinnych wolnostojących. Pośród kamienic najgorzej prezentują się te usytuowane na ul. Bydgoskiej, która wymaga jak najszybszej interwencji - modernizacji zabudowy, przeprowadzenia remontów i renowacji obiektów oraz poprawy kolorystyki elewacji frontowych, mających na celu przywrócenie walorów architektonicznych obszaru oraz poprawę jego wizerunku. Budynki są bowiem popękane, a ich elewacje bardzo nieestetyczne (ryc. 2). Widoczne są też ubytki pokrycia dachowego, uszkodzenia detali architektonicznych czy przestarzała, obdrapana stolarka okienna i drzwiowa. W niektórych przypadkach istnieje nawet poważne zagrożenie zawaleniem się budynku lub jego części (ryc. 3). Wśród tego typu zabudowy (zwłaszcza kamienic) wiele jest obiektów niezamieszkanych i nieużytkowanych. Zły stan zachowania zabudowy, liczne pustostany oraz tereny niezagospodarowane negatywnie wpływają na atrakcyjność osiedla i zmniejszają poczucie bezpieczeństwa wśród użytkowników takiej przestrzeni (zwłaszcza w godzinach wieczornych). Wyjątkiem wśród kamienic jest dobrze zadbana zabudowa ul. Sikorskiego.

Kolejnym istotnym elementem negatywnie wpływającym na postrzeganie Starego Fordonu w stosunku do innych osiedli jest blaszana zabudowa garażowa i nieestetyczne podwórka, występujące głównie w przypadku domów jednorodzinnych.

Liczba obiektów usługowych jest niewystarczająca i ogranicza się raczej jedynie do zaspokojenia najbardziej podstawowych potrzeb lokalnej ludności. Najbardziej odczuwalna jest uboga oferta usług gastronomicznych i kulturalno-rozrywkowych. Brakuje też miejsc służących integracji mieszkańców osiedla. Nawet sam rynek nie jest przestrzenią szczególnie zachęcającą społeczność Starego Fordonu do wspól-
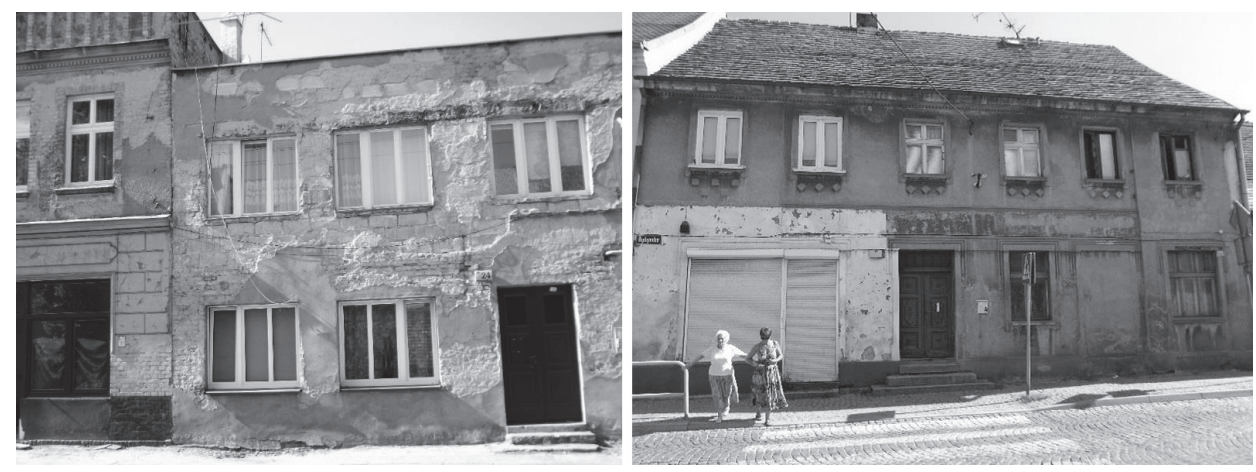

Ryc. 2. Zniszczone elewacje budynków przy ul. Bydgoskiej Źródło: fot. A. Lorek. 


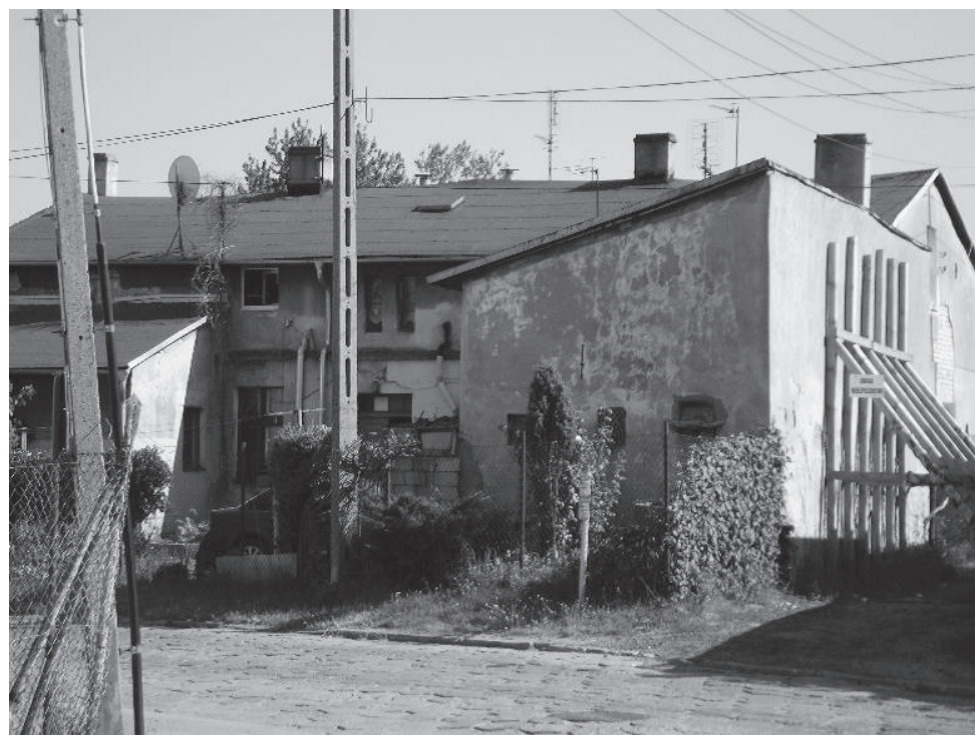

Ryc. 3. Budynek mieszkalny przy ul. Mącznej - grożący zawaleniem Źródło: fot. A. Lorek.

nego spędzania czasu. Ponadto należy dodać, że usytuowany tuż przy rynku zakład karny wzbudza mieszane uczucia i dysharmonizuje przestrzeń. Nie pasuje zarówno do charakteru i funkcji tego miejsca, jak i wyglądu spójnej pod względem wizualnym przedwojennej zabudowy.

Pod względem komunikacyjnym osiedle również nie przedstawia się zbyt dobrze. Dużym problemem mieszkańców Starego Fordonu jest dojazd do centrum Bydgoszczy. Najbardziej dotyka to osób dojeżdżających do pracy poza miejsce swojego zamieszkania. Stary Fordon położony jest w odległości ok. $12 \mathrm{~km}$ od centrum miasta. Pomimo zrealizowanej ostatnio ogromnej inwestycji władz miasta polegającej na poprowadzeniu linii tramwajowej do Fordonu sytuacja mieszkańców osiedla nie uległa tak dużej poprawie, jak się spodziewano. Trasa powstałego połączenia tramwajowego nie jest zbyt korzystna dla społeczności Starego Fordonu. Poza linią tramwajową na terenie osiedla funkcjonuje również jedna linia autobusowa, ale częstotliwość kursów jest dość mała.

\section{Sytuacja społeczna mieszkańców osiedla}

W ramach przygotowania niniejszej pracy przeprowadzona została, jak już wcześniej wspomniano, ankieta, pozwalająca na głębsze poznanie opinii na temat jakości życia na osiedlu Stary Fordon oraz codziennych problemów mieszkańców.

Część mieszkańców Starego Fordonu (15\%) pracuje na obszarze osiedla, ale wiele osób musi dojeżdżać do pracy w inne rejony miasta (65\%). Narzekają oni na długi czas dojazdów, źle rozplanowaną komunikację publiczną na terenie Bydgoszczy. Powodem 
podjęcia pracy poza miejscem zamieszkania są ograniczone możliwości znalezienia pracy w Starym Fordonie. Ankietowani przyczynę takiej sytuacji upatrują w likwidacji i zamknięciu wielu zakładów pracy, jakie kiedyś funkcjonowały na tym obszarze, np. cegielni, papierni, szkoły odzieżowej, a także portu i dużej bazy hotelowej. Pozostała grupa to osoby niepracujące (ryc. 4).

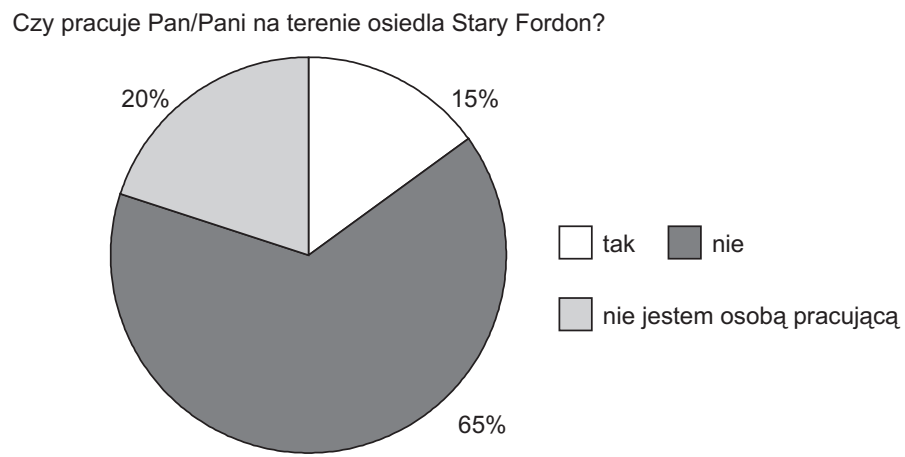

Ryc. 4. Udział ankietowanych pracujących w Starym Fordonie w ogólnej liczbie badanych

Źródło: opracowanie własne.

Stary Fordon kojarzy się osobom ankietowanym z cichym i spokojnym osiedlem peryferyjnym miasta. W ankiecie podkreślano wiejski lub małomiasteczkowy charakter Starego Fordonu m.in. ze względu na zlokalizowany w centrum osiedla rynek, typowy dla niewielkich miejscowości. Mieszkańcy osiedla, zwłaszcza ci starsi, są bardzo związani z historią Starego Fordonu i wciąż traktują go jak osobne miasto, którym niegdyś był. Pozytywne skojarzenia z osiedlem wiążą się z rodziną i ze spędzonym tam dzieciństwem (również dla osób, które już tam nie mieszkają). Dodatkowo cechą wyróżniającą Stary Fordon na tle innych osiedli jest lokalny patriotyzm i działanie na rzecz lokalnej społeczności. Wymieniono także skojarzenia negatywne - zły stan techniczny budynków i dróg, liczne pustostany i utrudniony dojazd do centrum Bydgoszczy. Poza tym wielu mieszkańców innych osiedli Stary Fordon kojarzy z zamieszkiwaniem przez ubogą, niższą klasę społeczną. W ankiecie tylko 6\% respondentów przyznało, że jest osobą korzystającą z pomocy społecznej, co nie odzwierciedla prawdziwej sytuacji. Według danych z tworzonego Gminnego Programu Rewitalizacji dla Bydgoszczy na rok 2015 aż 308 z 2079 (ok. 15\%) osób zamieszkałych na terenie osiedla Stary Fordon korzystało z pomocy społecznej (przy średniej dla Bydgoszczy na poziomie 5\%).

Większość osób ankietowanych (64\%) czuje się bezpiecznie na terenie osiedla Stary Fordon (ryc. 5). Niskie poczucie bezpieczeństwa dominuje wśród osób, które nie mieszkają tam na co dzień, tylko bywają sporadycznie. Zagrożone czują się zwłaszcza kobiety i osoby starsze. Zwracają oni uwagę na niewystarczający monitoring i oświetlenie w Sta- 
Czy czuje się Pan/Pani bezpiecznie w Starym Fordonie w porównaniu do innych osiedli Bydgoszczy?

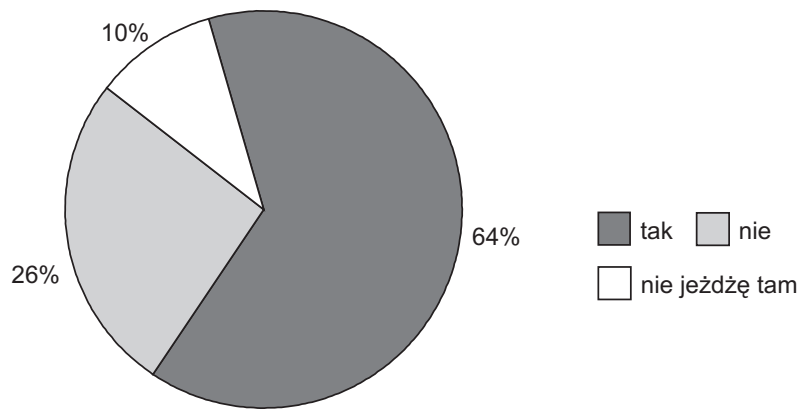

Ryc. 5. Rozkład odpowiedzi dotyczących poczucia bezpieczeństwa ankietowanych na osiedlu Stary Fordon

Źródło: opracowanie własne.

rym Fordonie oraz zbyt rzadkie patrole policji lub straży miejskiej. Z kolei mieszkańcy Starego Fordonu postrzegają osiedle jako bardzo bezpieczne i większość z nich nie ma żadnych negatywnych doświadczeń w tej kwestii. Niektórzy przyznają jednak, że w przeszłości przestępczość na tym obszarze faktycznie była większa (włamania, dewastacje, chuligaństwo), ale obecnie jest nie większa niż na innych bydgoskich osiedlach.

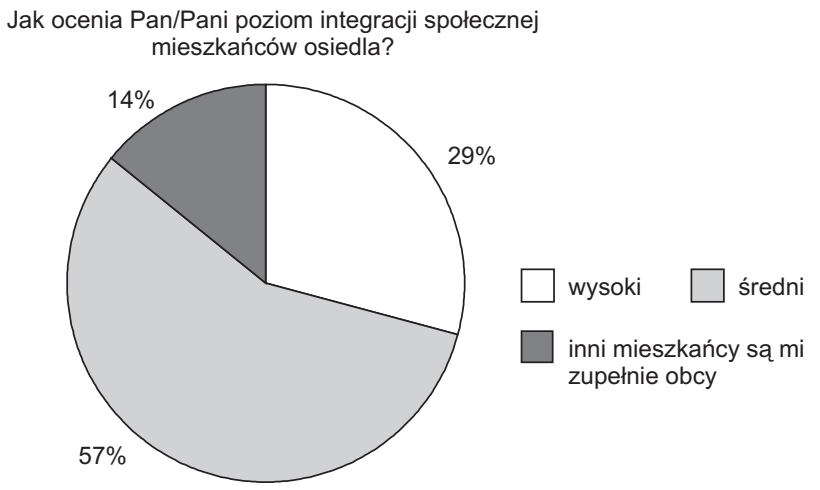

Ryc. 6. Rozkład odpowiedzi dotyczących oceny poziomu integracji społecznej mieszkańców osiedla Stary Fordon

Źródło: opracowanie własne.

W analizowanej ankiecie poproszono mieszkańców osiedla również o ocenę stopnia integracji lokalnej społeczności. 57\% respondentów uznało, że jest on średni, a 29\%, że wysoki (ryc. 6). Można więc uznać, że są oni dość dobrze zintegrowani ze sobą. Wynika to przede wszystkim ze specyficznego klimatu osiedla i więzi łączących jego mieszkańców. Ankietowani podkreślają ogromną rolę Stowarzyszenia Miłośników Starego 
Fordonu w promowaniu i zachęcaniu do działań korzystnych dla wspólnoty. Integrują one społeczność lokalną i są elementem rewitalizacji społecznej Starego Fordonu.

\section{Podejmowane próby rozpoczęcia rewitalizacji osiedla w latach 2004-2015}

Pierwsze plany dotyczące zarówno zmian przestrzennych, jak i poprawy sytuacji społeczno-gospodarczej na terenie osiedla znane były już w 2005 r. Powstał wtedy pierwszy Lokalny Program Rewitalizacji dla miasta Bydgoszczy, w którym Stary Fordon został wyznaczony jako jeden z obszarów objętych wsparciem i przeprowadzeniem działań rewitalizacyjnych. Niestety w związku z nową perspektywą funduszy europejskich na lata 2007-2013 Lokalny Program Rewitalizacji z 2005 r. przestał obowiązywać i zgodnie z nowymi wytycznymi do rewitalizacji trzeba było wybrać inne osiedla. Od tego czasu wszelkie planowane działania w Starym Fordonie były przesuwane na inny termin, a problemy mieszkańców bagatelizowane. Wyjątkiem stało się udzielenie przez władze Bydgoszczy i Sejmik Województwa Kujawsko-Pomorskiego w latach 2006-2012 wsparcia finansowego o łącznej wysokości 650000 zł na remont jednego z najcenniejszych zabytków osiedla - starej synagogi, należącej wówczas do Fundacji Kultury Yakiza (Janowski, Kawski 2009).

Przełom nastąpił w 2009 r. Ówczesne władze miasta rozpoczęły współpracę z holenderską firmą RDH i zleciły jej opracowanie tzw. Masterplanu dla Fordonu (ryc. 7). Przeprowadzono szerokie konsultacje społeczne, angażując w diagnozę potrzeb nie tylko mieszkańców, ale i przedsiębiorców. Efekty ich pracy zostały zaprezentowane w maju 2010 r. Projekt zakładał rewitalizację nabrzeży Wisły (wraz z remontem ulic mających zapewnić dostęp do terenów nadrzecznych), usytuowanie nad rzeką niektórych budynków kampusu Uniwersytetu Technologiczno-Przyrodniczego i wprowadzenie nowej zabudowy mieszkaniowej w okolicach Mostu Fordońskiego. Ponadto, teren dawnej cegielni miał zostać przystosowany do pełnienia funkcji mieszkaniowych i kulturotwórczych, podobnie jak zabytkowa synagoga przeznaczona na lokalny ośrodek kultury. Planowano też utworzenie parku o charakterze rekreacyjno-sportowym przy ul. Sielskiej ${ }^{3}$. Masterplan dla Fordonu okazał się piękną, ale utopijną wizją przyszłości. Niejasna okazała się kwestia finansowania projektu (według projektantów - z pieniędzy prywatnych inwestorów) i choć nie doczekał się on nigdy umocowania prawnego, prezydent miasta zapowiedział jego realizację. Krótko potem w Urzędzie Miasta Bydgoszczy nastąpiła zmiana władz i całkowita rezygnacja z projektu 4 .

Po upływie trzech lat powrócono do tematu rewitalizacji Starego Fordonu i Miejska Pracownia Urbanistyczna (MPU) we współpracy z Uniwersytetem Kazimierza Wielkiego opracowała koncepcję pn. „Stary Fordon - rewitalizacja funkcjonalno-przestrzenna” obowiązującą do dziś (ryc. 8). W stosunku do wcześniejszego Masterplanu projekt

\footnotetext{
3 www.bydgoszcz.pl.

4 okiembydgoszczanina.blogspot.com.
} 


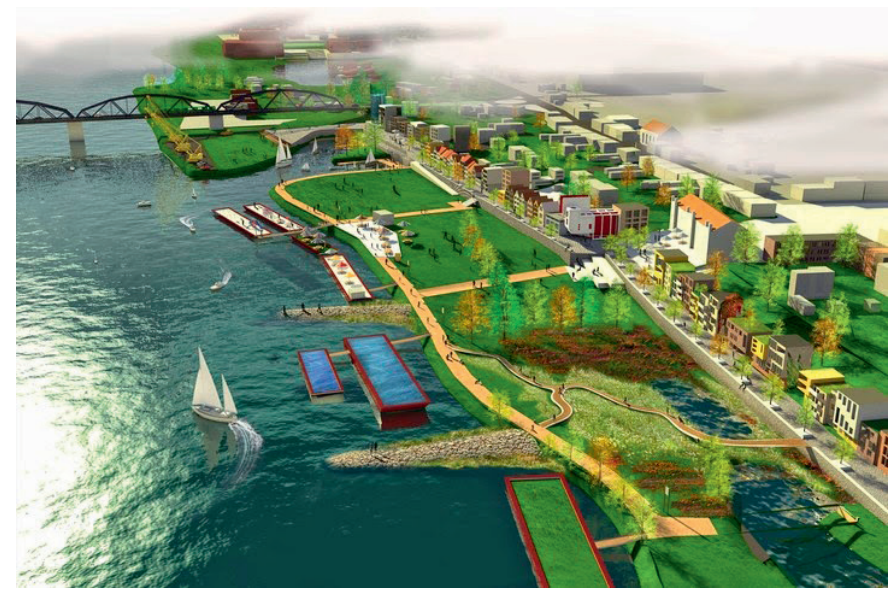

Ryc. 7. Projekt rewitalizacji Starego Fordonu opracowany przez holenderską firmę RDH

Źródło: okiembydgoszczanina.blogspot.com.

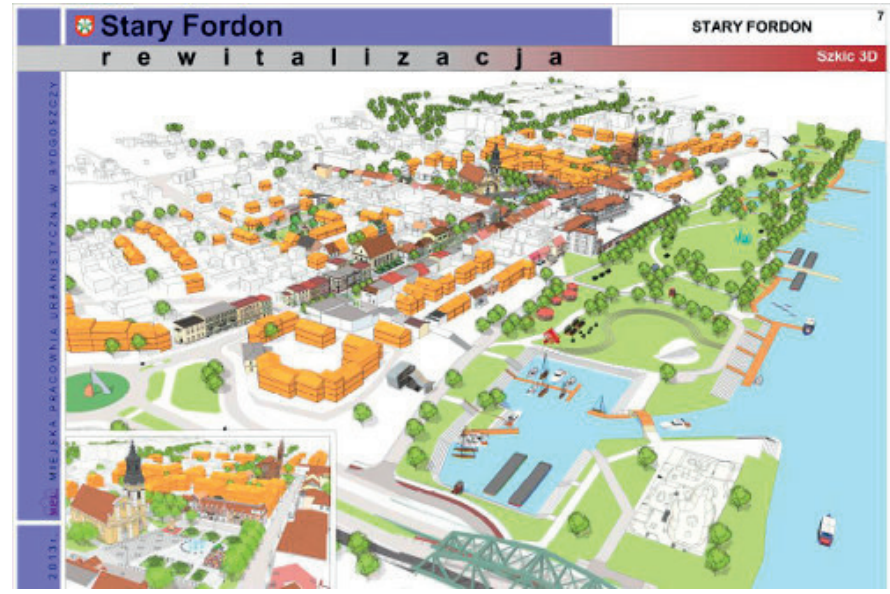

Ryc. 8. Koncepcja pn. „Stary Fordon - rewitalizacja funkcjonalno-przestrzenna" z 2013 r.

Źródło: www.bydgoszcz.pl.

MPU obejmował mniejszą powierzchnię terenu, pomijając działki położone przy ul. Fordońskiej. Projekt zakładał poprawę warunków mieszkaniowych i jakości życia ludności, stworzenie miejsca służącego integracji społecznej i ogólną poprawę estetyki osiedla (zwłaszcza terenów nad Wisłą). Wydaje się, że ta propozycja wpłynęłaby korzystnie na wizerunek całego miasta.

Początkowo kwota na realizację koncepcji pochodziła z budżetu miasta i była niewielka - udało się jedynie uporządkować dziką zieleń wzdłuż nabrzeży. Odbiło się to 
falą niezadowolenia ze strony mieszkańców, którzy stracili cierpliwość i nadzieję na to, że w ich życiu kiedykolwiek coś się zmieni, a zdewastowane osiedle zyska nowe oblicze. W październiku 2014 r. na wjeździe do Starego Fordonu mieszkańcy zorganizowali protest mający zwrócić uwagę władz na ich problemy i niedotrzymanie dawanych im wcześniej obietnic. To właśnie tego dnia najbardziej aktywni uczestnicy protestu założyli Stowarzyszenie Miłośników Starego Fordonu, które od tej pory występuje w interesie mieszkańców i przyczynia się do ich aktywizacji. Stowarzyszenie obecnie przejmuje wiele inicjatyw związanych z ożywieniem obszaru pod względem kulturalnym oraz poprawy wizerunku przestrzeni. W związku z protestem urzędnicy zaczęli intensywnie szukać możliwości pozyskania dofinansowania na dalszą realizację projektu Miejskiej Pracowni Urbanistycznej. Ostatecznie na realizację projektu udało się zabezpieczyć kwotę 50000000 zł w ramach Kontraktu Terytorialnego dotyczącego Zintegrowanych Inwestycji Terytorialnych, dzięki czemu kompleksowa rewitalizacja obszaru stała się realna i pewna. Na podstawie koncepcji MPU prowadzone są w tej chwili prace dotyczące szczegółowej dokumentacji techniczno-projektowej pierwszego etapu rewitalizacji Starego Fordonu - zagospodarowania terenu nabrzeży Wisły i jego najbliższego otoczenia. Komplementarnie do działań przestrzennych, po przeprowadzeniu kolejnych badań społecznych, w 2015 r. powstała też Społeczna Strategia Rewitalizacji Starego Fordonu.

\section{Obecna koncepcja rewitalizacji terenu}

Obszar Starego Fordonu pod względem planistycznym leży na terenie dwóch stref funkcjonalnych wyznaczonych w Studium Uwarunkowań i Kierunków Zagospodarowania Przestrzennego dla Miasta Bydgoszczy (2009). Większość osiedla znajduje się w strefie mieszkaniowej M8, która obejmuje Dolny Taras Fordonu, natomiast same nabrzeża Wisły w Starym Fordonie wchodzą w skład strefy dolin rzek D2 obejmującej tereny nadwiślańskie Fordonu (Studium Uwarunkowań... 2009) (ryc. 9). W Studium

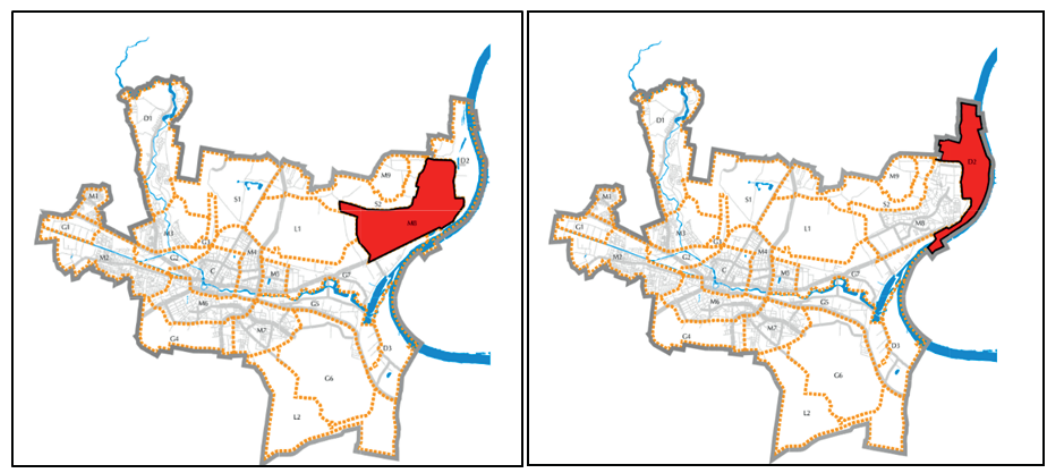

Ryc. 9. Strefy funkcjonalne M8 i D2, w obrębie których leży Stary Fordon Źródło: http://www.mpu.bydgoszcz.pl. 
zawarta jest ogólna charakterystyka tych terenów, ich cechy szczególne, a przede wszystkim podstawowe zasady ich zagospodarowania i kierunki rozwoju.

W ramach strefy M8 należy utrzymać i doprowadzić do dalszego rozwoju istniejącą zabudowę mieszkaniową (wielorodzinną, jednorodzinną i staromiejską) wraz z towarzyszącymi usługami podstawowymi. Istotne jest również zachowanie staromiejskiego charakteru zabudowy osiedla z uwzględnieniem wymogów konserwatorskich oraz ochrona istniejących i tworzenie nowych terenów zieleni wraz z obiektami o charakterze rekreacyjno-sportowym. Podstawową funkcją strefy D2 są natomiast obszary zieleni krajobrazowej i wód powierzchniowych, będące elementem miejskiego systemu przyrodniczego. W dużym stopniu są one objęte siecią Natura 2000. Około 30\% nabrzeża Wisły w Starym Fordonie znajduje się w granicach obszaru Natura 2000 - Dolina Dolnej Wisły (ostoja dla ptaków migrujących i zimujących). Zakazuje się w tym miejscu m.in. zabudowy brzegów oraz zalesiania muraw, zanieczyszczania wód czy niszczenia różnorodności biologicznej międzywala. Ponadto szereg ustalonych zakazów i ograniczeń dotyczących zagospodarowania tych terenów wynika z dość dużej podatności obszaru na zalewanie przez wody rzeczne Wisły (ryc. 10). Zaletą obszaru jest brak terenów zagrożonych osuwaniem się mas ziemnych. Występują natomiast dwie strefy ochrony konserwatorskiej. Zapisy Studium (2009) mówią też o tym, że należy zachować akwen portowy w rejonie ulicy Promenada w Starym Fordonie z możliwością jego powiększenia na potrzeby postoju sportowo-rekreacyjnych jednostek pływających.

Na podstawie zapisów zawartych w Studium (2009) tworzone są miejscowe plany zagospodarowania przestrzennego stanowiące uszczegółowienie dotyczące zasad za-

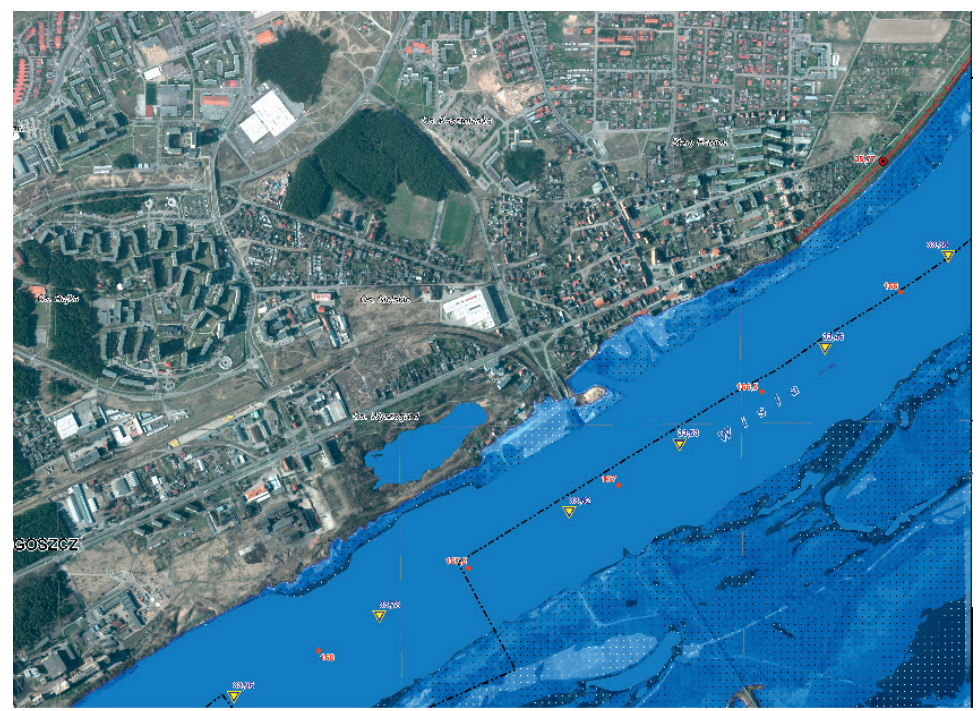

Ryc. 10. Mapa zagrożenia powodziowego w Starym Fordonie wraz ze wskazaniem głębokości wody, prawdopodobieństwo wystąpienia powodzi $1 \%$ - raz na 100 lat Źródło: http://mapy.isok.gov.pl/pdf/N34097/N34097Cb1_ZG_1.pdf. 
gospodarowania każdego z podobszarów wyznaczonych w planie. Plan miejscowy jest aktem prawa miejscowego i zakazów oraz nakazów w nim zawartych należy bezwzględnie przestrzegać. Obecnie plan miejscowy dla obszaru Starego Fordonu nie został jeszcze uchwalony, ale projekt planu jest na etapie konsultacji społecznych, wyłożony do wglądu publicznego (ryc. 11).

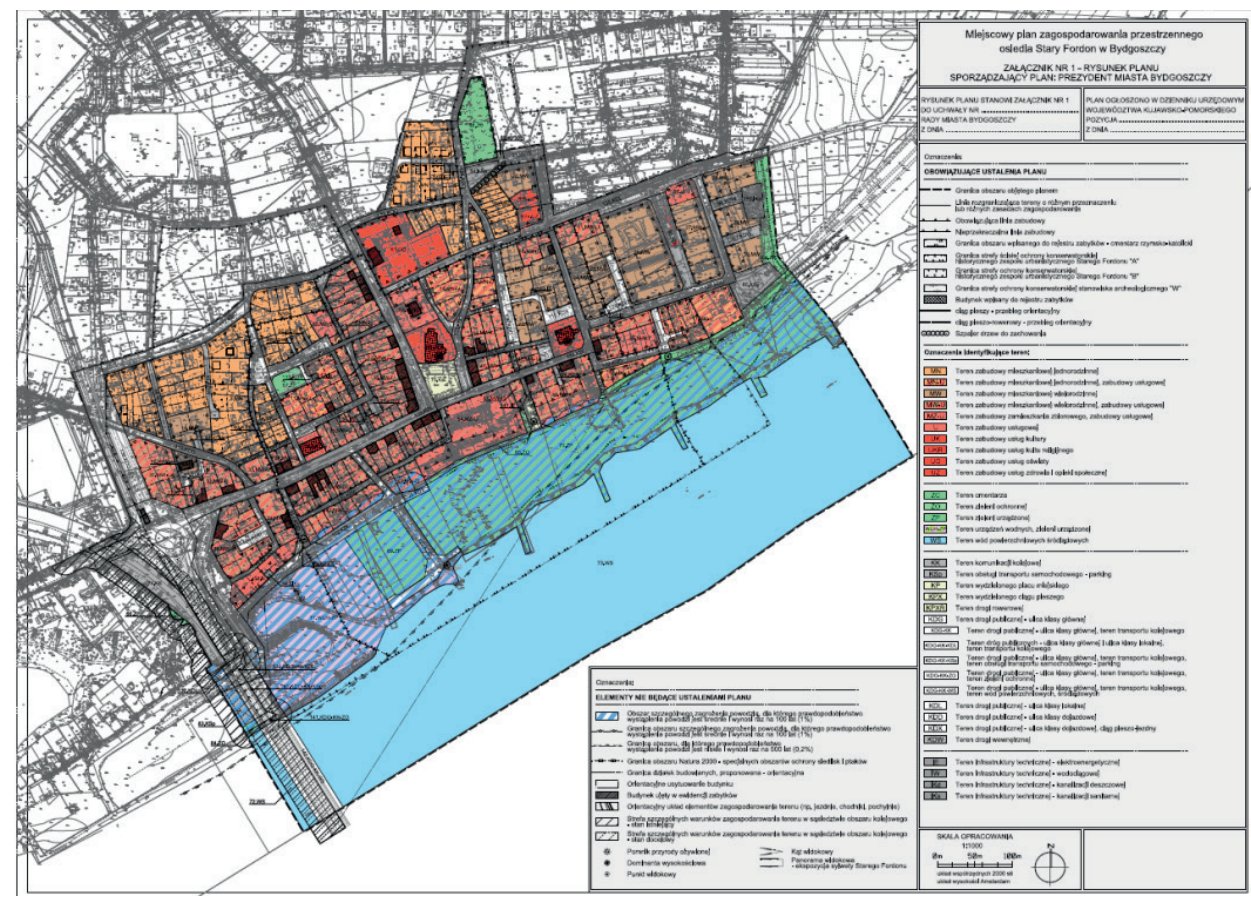

Ryc. 11. Projekt planu miejscowego „Stary Fordon”

Źródło: http://www.mpu.bydgoszcz.pl/216_mpzp_.zip.

Innym dokumentem odnoszącym się do nabrzeży Wisły w Starym Fordonie jest Program Rewitalizacji i Rozwoju Bydgoskiego Węzła Wodnego, sporządzony w 2006 r. przez Miejską Pracownię Urbanistyczną. Opracowanie ma na celu przywrócenie Bydgoszczy tożsamości miasta położonego nad rzekami i kanałem. Bydgoski Węzeł Wodny (BWW) to jeden z najważniejszych zasobów środowiskowych miasta. Składają się na niego: Wisła, Brda, Kanał Bydgoski oraz mniejsze strugi wodne na obszarze Bydgoszczy wraz z nabrzeżami i urządzeniami hydrotechnicznymi. W programie wydzielone zostało pięć stref krajobrazowych, dla których określono wytyczne dotyczące ich zagospodarowania i dalszego rozwoju (Program Rewitalizacji... 2006).

Nabrzeża rzeczne Starego Fordonu leżą w strefie krajobrazowej „Wisła”. Charakteryzują się dużą liczbą niezagospodarowanych terenów otwartych, łąkowych i niewielką liczbą obszarów zabudowanych. Występują też liczne zadrzewienia łęgowe oraz wały 
przeciwpowodziowe. Wisła jest nieuregulowana, żeglowna. W wytycznych dla tego obszaru wskazano: potrzebę utworzenia na wale przeciwpowodziowym bulwaru (wraz z miejscami do wypoczynku, restauracjami i przystanią rzeczną) oraz parku dzielnicowego, uporządkowanie i urządzenie zieleni, a także iluminację najważniejszych obiektów. Ponadto zaproponowano uruchomienie przewozów pasażerskich po Wiśle oraz uporządkowanie terenów eksploatacji kruszywa w okolicach mostu (Program Rewitalizacji... 2006).

Pod względem planistycznym jedną z najważniejszych kwestii jest też istnienie dwóch stref ochrony konserwatorskiej na terenie Starego Fordonu - strefy A i strefy B. Strefa A to obszar pełnej ochrony konserwatorskiej, wyznaczany dla terenów szczególnie wartościowych i bogatych w zabytki. Stary Fordon został objęty ochroną w ramach tej strefy ze względu na bardzo dobrze zachowany historyczny układ urbanistyczny i zabudowę oraz krajobraz zachowany w stanie niemal niezmienionym. Strefą A objęta jest lokacyjna, najstarsza część Fordonu. Strefa B ochrony pośredniej to obszar najbliższego otoczenia części lokacyjnej, gdzie również w znacznym stopniu i dosyć dobrze zachował się historyczny układ urbanistyczny i obiekty zabytkowe (cmentarze). W przypadku obu stref należy zadbać o zachowanie odpowiedniego charakteru i skali nowej zabudowy. Do obszarów i obiektów wpisanych do rejestru zabytków województwa kujawsko-pomorskiego, znajdujących się na terenie Starego Fordonu, zaliczane są dwa kościoły - kościół pw. św. Mikołaja (ul. Wyzwolenia, przy rynku) i kościół ewangelicki pw. św. Jana (ul. Sikorskiego), a także dawna synagoga żydowska i dwa cmentarze. Cmentarz rzymskokatolicki pochodzący z końca XVIII w. położony jest przy ul. Cechowej. Drugi zaś z cmentarzy wraz z kaplicą cmentarną znajduje się poza obszarem do rewitalizacji, ale w granicach osiedla - na ul. Piastowej. Wszystkie zabytki mają zatem charakter sakralny i są pozostałością po ludności trzech różnych kultur, które niegdyś razem zamieszkiwały ten obszar (http://www.mpu.bydgoszcz.pl; Program Rewitalizacji... 2006).

Obecnie Stary Fordon jest jednym z osiedli wyznaczonych do rewitalizacji w nowym Gminnym Programie Rewitalizacji Bydgoszczy, co umożliwi szybkie rozpoczęcie intensywnych działań naprawczych na tym terenie. W 2013 r. Miejska Pracownia Urbanistyczna sporządziła kompleksowe opracowanie „Stary Fordon - rewitalizacja funkcjonalno-przestrzenna", które wyznacza kierunki rewitalizacji osiedla i jest obowiązującą podstawą do działań projektowych. Zarząd Dróg Miejskich i Komunikacji Publicznej w Bydgoszczy przygotował wstępną koncepcję do pierwszego etapu rewitalizacji Starego Fordonu, który będzie dotyczyć nabrzeży Wisły oraz dróg zapewniających dostęp do tego terenu. W drodze przetargu został już wyłoniony wykonawca dokumentacji technicznej projektu pierwszego etapu rewitalizacji i przedstawił on swój wstępny pomysł zagospodarowania terenów nadwiślańskich w Starym Fordonie.

Na podstawie opracowania MPU rozpoczęto pierwszy etap rewitalizacji - zadanie „Rewitalizacja społeczno-gospodarcza Starego Fordonu - etap I” dotyczące zagospodarowania nabrzeży i zwiększenia ich dostępności komunikacyjnej. Wyłoniona w przetargu firma Pas Projekt przedstawiła wstępnie swoją propozycję. Projekt można podzielić 
na dwie części - drogową i rekreacyjną. Część drogowa będzie polegać na budowie, rozbudowie i przebudowie dróg znajdujących się pomiędzy Wisłą a ul. Bydgoską. Promenada ma zostać przedłużona i poprowadzona na umocnionym wale przeciwpowodziowym. Zostanie ona połączona z ul. Nad Wisłą i będzie stanowiła oś projektu. W części rekreacyjnej wzdłuż promenady zlokalizowana zostanie mała architektura w postaci stojaków na rowery, ławek i koszy oraz dwie siłownie zewnętrzne. Poza nią teren podzielono na trzy strefy. W strefie sportowej znajdować się będą skatepark, ścianki wspinaczkowe, letnia siłownia i plac zabaw, a także boisko do siatkówki plażowej i betonowy tor rowerowy. Drugą strefą jest polana rekreacyjna, na której będą mogły się odbywać różne zajęcia plenerowe i wydarzenia kulturalne. Ostatnią strefę, położoną najbardziej na wschód, stanowi obszar Natura 2000 i zostaną tam postawione tylko tabliczki edukacyjno-przyrodnicze ${ }^{5}$.

Dodatkowo ważnym elementem rewitalizacji jest Społeczna Strategia Rewitalizacji Starego Fordonu, której założenia wykorzystane zostaną w Gminnym Programie Rewitalizacji Bydgoszczy. Organizatorem procesu powstania strategii była Fundacja UKW we współpracy z Pracownią Zrównoważonego Rozwoju z Torunia. Opracowanie to jest wizją mieszkańców Starego Fordonu ukazującą ich pomysły na zmiany na terenie osiedla w ciągu najbliższych lat. Składa się ona z czterech głównych celów strategicznych, do których przyporządkowano cele operacyjne i konkretne zadania pozwalające te cele osiągnąć. Cele strategiczne dotyczą: zapewnienia dobrych warunków do życia i mieszkania, rozwoju lokalnego biznesu, zwiększenia atrakcyjności turystycznej osiedla oraz zapewnienia spójności społecznej. Poza remontami budynków i nawierzchni ulic oraz odnowieniem elewacji kamienic wskazano potrzebę powołania społecznych opiekunów zabytków. Na terenach nadwiślańskich zaproponowano m.in. utworzenie kina plenerowego i przenośnej sceny, a także wybiegu dla zwierząt i toru rolkowego. Mieszkańcy chcą też, aby na terenie Starego Fordonu powstały: stacja Bydgoskiego Roweru Aglomeracyjnego, targowisko, publiczne toalety, ogólnodostępny ogród warzywny i aby organizowane były konkursy na najbardziej ukwiecony ogród lub balkon. Sugeruje się też poprawę komunikacji publicznej i budowę przystanku tramwaju wodnego nad Wisłą 6 .

\section{Ocena koncepcji i proponowanych zmian na terenie Starego Fordonu}

Obowiązująca koncepcja rewitalizacji była wielokrotnie analizowana i poddawana modyfikacjom. Powstałe opracowanie MPU przedstawia w sposób bardzo szczegółowy i bogaty graficznie wszystkie uwarunkowania Starego Fordonu i potrzeby zgłaszane przez jego mieszkańców, a także kierunki rozwoju osiedla. Ogólne wytyczne i idee zawarte w opracowaniu budzą pozytywne odczucia, są starannie dobrane i przemyś-

\footnotetext{
5 http://www.zdmikp.bydgoszcz.pl.

6 http://www.fundacja.ukw.edu.pl.
} 
lane. W szczególności należy docenić też fakt nawiązania do historii i dziedzictwa kulturowego Starego Fordonu. Nie oznacza to jednak, że wszystkie rozwiązania przyjęte w dokumencie MPU muszą zostać zrealizowane dokładnie we wskazany tam sposób, a przygotowana koncepcja nie mogłaby zostać delikatnie zmieniona i wzbogacona o nowe elementy. Przykładowo zbędne wydaje się utworzenie na skrzyżowaniu ulic Ordynackiej i Cierpickiej miejsca wypoczynku na tak dużą skalę, jak zostało to zaplanowane (ogrody letnie, kawiarnie, restauracje), czy też powstanie elementów małej architektury w bardzo nowoczesnej, niepasującej do otoczenia stylistyce.

Opracowanie podzielono na trzy części - opis uwarunkowań i kierunków rozwoju oraz przedstawienie w formie graficznej zarówno uwarunkowań, jak i kierunków. Teren podzielono na pięć rejonów funkcjonalno-przestrzennych: „Rynek - Sikorskiego”, „Targowisko - Synagoga”, „Bydgoska”, „Bulwar Nadwiślański” i „Rondo Buxakowskiego”. Wszystkie te części składają się w jedną całość i połączone są trasą pn. „Spacer po Starym Fordonie"7.

Proponowane rozwiązania opierają się głównie na działaniach o charakterze przestrzennym. W sferze transportowej planowane są: poprawa stanu dróg poprzez budowę nawierzchni istniejących dróg gruntowych, przebudowa ronda Buxakowskiego czy utworzenie parkingów w pobliżu Wisły. Powstać mają też ciągi rowerowe i piesze wzdłuż terenów nadwiślańskich oraz port rzeczny na potrzeby rozwoju turystyki wodnej. Poza tym koncepcja zakłada uzupełnienie zabudowy i zagospodarowanie pustostanów, głównie na funkcje usługowe. Niezbędne jest też przywrócenie ładu przestrzennego oraz estetyki zniszczonych elewacji. Przede wszystkim jednak najważniejszym założeniem jest utworzenie terenów o funkcjach sportowo-rekreacyjnych i rozrywkowych, które zaktywizują lokalną społeczność i będą pełnić rolę integracyjną. Głównym obszarem rekreacji mają być tereny nadwiślańskie. Zaplanowano utworzenie tam bulwaru, portu, sceny letniej i miejsc do grillowania, a także lokalizację urządzeń do ćwiczeń i ścieżki edukacyjno-przyrodniczej. Przy bulwarze, we wschodniej części obszaru, jeden z istniejących budynków ma pełnić funkcje hotelarsko-gastronomiczne. Drugi teren rekreacyjny ma być usytuowany na pustym placu przy ul. Targowisko i składać się z: siłowni zewnętrznej, placu zabaw oraz obiektu usługowego, gdzie prowadzona będzie opieka nad dziećmi i doradztwo dla osób bezrobotnych. Funkcje kulturalne ma pełnić dawna synagoga żydowska, gdzie utworzony zostanie ośrodek kultury i historii Fordonu ${ }^{8}$.

Kluczowe przy planowaniu procesu rewitalizacji osiedla Stary Fordon, a zwłaszcza jego pierwszego etapu, jakim jest zagospodarowanie terenów nadwiślańskich, było uwzględnienie ograniczeń związanych z występowaniem w tym miejscu obszaru Natura 2000 oraz terenów zalewowych. Zagrożenie powodziowe dotyczy w zasadzie całego obszaru nabrzeży. W związku z tym elementy projektowane w ramach pierwszego

\footnotetext{
7 http://www.mpu.bydgoszcz.pl.

8 http://www.mpu.bydgoszcz.pl.
} 
etapu rewitalizacji powinny być w miarę możliwości odporne na podmywanie przez wodę lub łatwe do odbudowania w przypadku wystąpienia powodzi. Bardzo dobrym rozwiązaniem jest też wykorzystanie obiektów tymczasowych, które dają dużo różnych możliwości zagospodarowania.

Wstępna koncepcja projektowa dla nabrzeży przedstawiona przez firmę Pas Projekt zależnie od odbiorcy także może wzbudzać pewne wątpliwości i mieszane odczucia. Generalnie projekt wpisuje się w opracowanie wykonane przez MPU, a nawet wzbogaca obszar Natura 2000 o budki dla ptaków i trzmieli. W praktyce jednak projekt skupia się głównie na przebudowie dróg zapewniających dostęp do bulwaru i budowie parkingów, a zagospodarowanie ogromnego terenu nabrzeży traktowane jest w sposób ewidentnie marginalny. Projektowany teren sportowy jest dość atrakcyjny, lecz wyraźnie widoczna jest duża powierzchnia terenów niezagospodarowanych. Jednocześnie firma proponuje utworzenie aż trzech siłowni plenerowych nad Wisłą. Popularność takich urządzeń jest ostatnio bardzo duża, ale korzystniej byłoby przeznaczyć te środki finansowe na inne atrakcje, chociażby w formie zabudowy tymczasowej czy wydarzeń kulturalnych. Z odpowiedzi ankietowanych dotyczącej tego, czego im najbardziej w Starym Fordonie brakuje, wyraźnie wynika, że poza poprawą stanu technicznego są to kultura i rozrywka (ryc. 12). Mile widziane byłyby również miejsca sportu i rekreacji, punkty gastronomiczne oraz poprawa komunikacji publicznej.

Czego najbardziej brakuje Pani/Panu w Starym Fordonie?

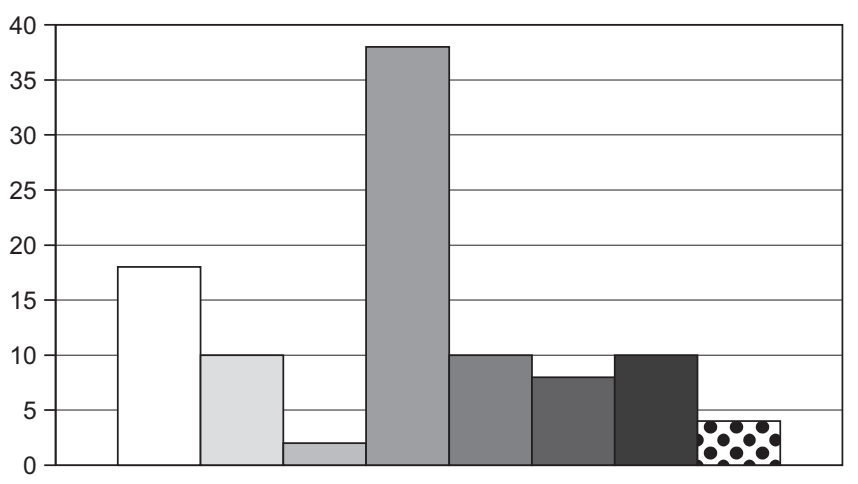
kultury i rozrywki
miejsc sportu i rekreacji
lepszej jakości środowiska
dobrego stanu technicznego zabudowy i infrastruktury
bazy gastronomiczej
ścieżek rowerowych
dobrej komunikacji publicz-
nej $z$ centrum miasta

inne

Ryc. 12. Rozkład odpowiedzi dotyczących największych potrzeb osiedla Stary Fordon według ankietowanych Źródło: opracowanie własne.

Poniżej przedstawiona została alternatywa dla obecnie obowiązującej koncepcji rewitalizacji, zawierająca propozycje drobnych zmian proponowanych przez samych mieszkańców Starego Fordonu i inspiracje autorów niniejszej pracy.

Projekt dzieli obszar nabrzeży na pięć podobszarów: Strefę Przystani, Strefę Aktywnej Rekreacji, Strefę Sportów Ekstremalnych, Strefę Kultury i Wypoczynku oraz Strefę Natury. Istotnym założeniem projektu jest zachowanie spójnej stylistyki. Dotyczy to 
zarówno obszaru rynku i głównych ulic, jak i terenów nad Wisłą. Okolice rynku pod względem materiałów i kolorystyki należy kształtować w stylu małomiasteczkowym lub retro. Wszystkie obiekty na nabrzeżu natomiast powinny być wykonane z drewna lub z tworzywa w kolorze niebieskim, nawiązującym do wody. Mieszkańcy Starego Fordonu wnosili uwagi dotyczące projektu firmy Pas Projekt, słusznie zauważając, że jedynie w niewielkim stopniu spełnia on wymóg przywracania mieszkańcom i odwiedzającym poczucia nadrzecznej tożsamości.

W alternatywnym projekcie zakłada się utworzenie jednej siłowni plenerowej wzdłuż promenady w formie ścieżki zdrowia. Przy bulwarze musi też zostać założona stacja Bydgoskiego Roweru Aglomeracyjnego. W Strefie Przystani, poza planowaną w koncepcji firmy Pas Projekt przystanią przeznaczoną głównie dla kajakarzy, proponuje się lokalizację przystanku tramwaju wodnego oraz przeznaczenie pobliskiego budynku na funkcje noclegowo-gastronomiczne wraz z wypożyczalnią sprzętu wodnego. W pierwotnej koncepcji obiekt przeznaczony na hotel znajdował się po przeciwnej stronie nabrzeża. Zmiana, jaka mogłaby nastąpić, wynika z ustaleń miejscowego planu zagospodarowania przestrzennego oraz względów praktycznych (m.in. możliwość prowadzenia wypożyczalni sprzętu wodnego przez właścicieli budynku). Jako dodatkowa atrakcja zaprojektowana została też drewniana wieża widokowa.

Drugą strefą jest Strefa Aktywnej Rekreacji. Usytuowane zostało tam boisko do siatkówki plażowej oraz dwa tzw. basketball trees przeznaczone do ćwiczenia rzutów do kosza. W dalszej części znajdować się będą niezbyt wysokie ścianki wspinaczkowe o urozmaiconych kształtach. Taki rodzaj ścianek wspinaczkowych umożliwia korzystanie z nich samodzielnie, bez asekuracji. Na polanie bliżej Wisły zamiast typowego placu zabaw dla dzieci rozmieszczone zostaną wykonane z drewna i innych materiałów naturalnych gry logiczne oraz gry pozwalając na naukę poprzez zabawę. Ostatnią atrakcją tego podobszaru byłby basen umieszczony na specjalnej barce na Wiśle z możliwością podgrzewania wody i korzystania z niego całorocznie. Dojście do basenu zapewniałyby pomosty, które mogłyby też służyć jako miejsce wypoczynku.

Dalej na wschód planowane jest utworzenie Strefy Sportów Ekstremalnych, składającej się z naturalnie ukształtowanego toru rowerowego oraz niewielkiego drewnianego skateparku. Proponowany park rowerowy może być ciekawszą i lepiej skomponowaną z otoczeniem propozycją niż betonowy pumptrack z koncepcji Pas Projektu.

Kolejny podobszar stanowi polana rekreacyjna - Strefa Kultury i Wypoczynku. Jest to miejsce, gdzie odbywałyby się różne wydarzenia kulturalne, imprezy, koncerty czy też zajęcia plenerowe (np. joga, plenery malarskie). Zgodnie z ustaleniami miejscowego planu zagospodarowania przestrzennego można tu lokalizować wszelkiego rodzaju zabudowę tymczasową. Coraz popularniejszym pomysłem jest wykorzystywanie kontenerów na potrzeby warsztatów czy małej gastronomii. Obiektem tymczasowym mogą być też tory do gry w bule oraz czasowe wystawy sztuki.

Ostatni podobszar terenów nadwiślańskich to Strefa Natury znajdująca się na obszarze chronionym Natura 2000. Koncepcja zagospodarowania tej strefy jest identyczna z przedstawioną przez firmę Pas Projekt. 
Poza zagospodarowaniem terenów nabrzeży Wisły proponuje się utworzenie profesjonalnego wybiegu dla psów na terenie dawnej żwirowni. Działanie kawiarni społecznej Cafe Rynek oraz lokalnego centrum kultury w budynku dawnej synagogi (razem z Ogrodem Uprawy Sztuki) powinno zostać podtrzymane i dalej się rozwijać.

\section{Podsumowanie}

Stary Fordon to obszar o dużej wartości i potencjale dotyczącym zarówno zasobów przestrzeni, jak i mieszkańców, których wyróżnia na tle innych bydgoskich osiedli ogromne przywiązanie do swojego miejsca zamieszkania. Dzięki temu bardzo chętnie angażują się oni we wszelkie inicjatywy na rzecz lokalnej społeczności. Zabudowa Starego Fordonu to cenne dziedzictwo historyczno-kulturowe od lat zachowane w niezmienionej formie. Dodatkowym atutem jest niepowtarzalne położenie obszaru nad Wisłą. Jednocześnie teren ten był bardzo zaniedbany i zapomniany. Według danych statystycznych zawartych w Gminnym Programie Rewitalizacji jest to osiedle o największym nagromadzeniu problemów społecznych. Jego rewitalizacja stała się więc konieczna. Ogólna ocena obecnie obowiązującej koncepcji jest pozytywna. Trzeba jednak przyznać, że projekt firmy Pas Projekt nie spełnia wszystkich potrzeb mieszkańców. Dla osiągnięcia lepszych efektów zaproponowane zostały elementy, które mogłyby go wzbogacić - uczynić bardziej atrakcyjnym turystycznie, zaktywizować i zintegrować mieszkańców. Należałoby rozwinąć przede wszystkim działania miękkie, społeczne. Nadanie odpowiedniego charakteru tym terenom i podkreślenie ich wyjątkowości poprzez określoną stylistykę byłoby czymś niezwykle rzadkim w czasach postępującej globalizacji i unifikacji przestrzeni. Efektem kompleksowo przeprowadzonej rewitalizacji byłyby korzyści dla całego miasta Bydgoszczy, które od jakiegoś czasu rozwój swój opiera na przywróceniu relacji z rzekami.

Szczególnie pozytywnym aspektem rewitalizacji Starego Fordonu jest aktywny udział mieszkańców obszaru w całym procesie. Zjawisko takie jest wciąż jeszcze rzadko spotykane i może stanowić wzór dla innych miast Polski. Zaangażowanie lokalnej społeczności, która w miarę własnych możliwości stara się część działań rewitalizacyjnych realizować samodzielnie, może się przyczynić do wyrównania niektórych braków w koncepcji firmy Pas Projekt. Jedynym poważnym mankamentem proponowanego projektu jest niewystarczająca liczba atrakcji planowanych na terenach nadwiślańskich, którą należy zwiększyć.

\section{Bibliografia}

Banaszak J., 1996, Środowisko przyrodnicze Bydgoszczy, Tannan, Bydgoszcz.

Biegański Z., 1997, Dzieje Fordonu i okolic, Wydanictwo Kujawsko-Pomorskie, Bydgoszcz.

Ferber U., Nathanail P., Jackson J., Gorski M., Krzywon R., Drobiec L., Petrikova D., Finka M., 2006, Tereny zdegradowane, Projekt pilotażowy Leonardo da Vinci.

Herbst K., 2008, Społeczny sens rewitalizacji, „Ekonomia Społeczna. Teksty” nr 3. 
Jankowski A., 2011, Zabytkowa bóżnica murowana w Bydgoszczy-Fordonie w świetle najnowszych badań, „Kwartalnik Architektury i Urbanistyki” nr 56(2).

Janowski A., Kawski T., 2009, Żydzi w Fordonie. Dzieje. Kultura. Zabytki, Mado, Bydgoszcz.

Kaczmarek J., 2010, Zarzadzanie wizerunkiem miasta - uwagi heurystyczne, „Studia Miejskie” t. 1.

Kaczmarek S., 2001, Rewitalizacja obszarów poprzemysłowych. Nowy wymiar w rozwoju miast, Wydawnictwo Uniwersytetu Łódzkiego, Łódź.

Kondracki J., 2001, Geografia regionalna Polski, Wydawnictwo Naukowe PWN, Warszawa.

Kotus J., 2005, Społeczne dylematy w przestrzeni miejskiej, Bogucki Wydawnictwo Naukowe, Poznań.

Lorens P., 2009, Wybrane zagadnienia rewitalizacji miast, Urbanista, Gdańsk.

Madurowicz M., 2002, Sfera sacrum w przestrzeni miejskiej Warszawy, Wydawnictwo Akademickie „Dialog”, Warszawa.

Niezabitowska E., 2015, Wyzwania badawcze w architekturze w świetle problemów starzejącego się społeczeństwa. Ze szczególnym uwzględnieniem środowiska zamieszkania, „Społeczeństwo i Edukacja. Międzynarodowe studia humanistyczne" nr 1.

Parysek J.J., 2005, Miasta polskie na przełomie XX i XXI wieku: rozwój i przekształcenia strukturalne, Bogucki Wydawnictwo Naukowe, Poznań.

Program Rewitalizacji i Rozwoju Bydgoskiego Węzła Wodnego, 2006, Miejska Pracownia Urbanistyczna, Bydgoszcz, http://bip.um.bydgoszcz.pl (dostęp 15 czerwca 2018).

Rysz-Kowalczyk B. (red.), 2001, Leksykon polityki społecznej, Aspra-Jr, Warszawa.

Społeczna Strategia Rewitalizacji Starego Fordonu, www.fundacja.ukw.edu.pl/ (dostęp 15 czerwca 2018).

Studium Uwarunkowań i Kierunków Zagospodarowania Przestrzennego Miasta Bydgoszczy, 2009, Miejska Pracownia Urbanistyczna, Bydgoszcz.

Szafrańska E., 2010, Wielkie zespoty mieszkaniowe - ich przemiany i miejsce w strukturze spoteczno-przestrzennej wspótczesnego miasta. Przykład Łodzi, „Studia Miejskie” t. 2.

Szarfenberg R., 2007, Ubóstwo, marginalność i wykluczenie społeczne, [w:] Firlit-Fesnak G., Szylko-Skoczny M. (red.), Polityka spoleczna, Wydawnictwo Naukowe PWN, Warszawa.

Šafránková J., 2005, Urban revitalization and possibilities of public participation, „Teka Komisji Architektury, Urbanistyki i Studiów Krajobrazowych OL PAN" 1.

Ustawa z dnia 9 października 2015 r. o rewitalizacji, Dz.U. z 2015 r., poz. 1777 z późn. zm.

Wańkowicz W., 2011, Rewitalizacja i planowanie przestrzenne stref społecznie wykluczonych, Instytut Rozwoju Miast, Kraków.

http://mapy.isok.gov.pl/pdf/N34097/N34097Cb1_ZG_1.pdf (dostęp 15 czerwca 2018).

okiembydgoszczanina.blogspot.com (dostęp 15 czerwca 2018).

wikimapia.org (dostęp 15 czerwca 2018).

www.bydgoszcz.pl (dostęp 15 czerwca 2018).

www.mpu.bydgoszcz.pl (dostęp 15 czerwca 2018).

www.staryfordon.pl (dostęp 15 czerwca 2018).

www.zdmikp.bydgoszcz.pl (dostęp 15 czerwca 2018). 